\title{
Evaluation of Antidiabetic Activity of Sargassum tenerrimum in Streptozotocin-Induced Diabetic Mice
}

\author{
A. Philomena Joy Lindsey ${ }^{1}$, Reya Issac ${ }^{2}$, M. Lakshmi Prabha², R. Emilin Renitta ${ }^{1 *}$, \\ Angeline Catherine ${ }^{2}$, Antony V. Samrot ${ }^{3 *}$ (D) S. Abirami ${ }^{4}$, P. Prakash ${ }^{5}$ and S. Dhiva ${ }^{6}$
}

\footnotetext{
${ }^{1}$ Department of Food Processing Technology, School of Agriculture and Biosciences, Karunya Institute of Technology and Sciences, Coimbatore - 641 114, Tamil Nadu, India.

${ }^{2}$ Department of Biotechnology, School of Agriculture and Biosciences, Karunya Institute of Technology and Sciences, Coimbatore - 641 114, Tamil Nadu, India.

${ }^{3}$ School of Bioscience, Faculty of Medicine, Bioscience and Nursing, MAHSA University, Jalan SP2, Bandar Saujana Putra, 42610, Jenjarom, Selangor, Malaysia.

${ }^{4}$ Department of Microbiology, Kamaraj College, Thoothukudi - 628 003, Tamil Nadu, India.

${ }^{5}$ Department of Biotechnology, School of Bio and Chemical Engineering, Sathyabama Institute of Science and Technology, Chennai - 600 119, Tamil Nadu, India.

${ }^{6}$ Department of Microbiology, Sree Narayana College, Alathur, Palakkad, Kerala - 678 682, Kerala, India.
}

\section{*Correspondence: emilinrenitta@gmail.com; antonysamrot@gmail.com}

(Received: June 18, 2021; accepted: October 15, 2021)

Citation: Lindsey APJ, Issac R, Prabha ML, et al. Evaluation of Antidiabetic Activity of Sargassum tenerrimum in StreptozotocinInduced Diabetic Mice. J Pure App/ Microbiol. 2021;15(4):2462-2472. doi: 10.22207/JPAM.15.4.73

C The Author(s) 2021. Open Access. This article is distributed under the terms of the Creative Commons Attribution 4.0 International License which permits unrestricted use, sharing, distribution, and reproduction in any medium, provided you give appropriate credit to the original author(s) and the source, provide a link to the Creative Commons license, and indicate if changes were made. 


\begin{abstract}
Diabetes mellitus has become the most predominant disease in most of the developing and developed countries. Diabetes could occur at any stage of life for which a change in sedentary life style is the possible solution. Despite the introduction of several medications, to curtail the side effects associated with diabetes mellitus, there is no medication or treatment for complete cure. Existing medications and treatments are targeted to mitigate the intensity of the disease which abruptly could result in organ failure. Rather than the available types of treatments, natural medication is reported to produce commendable results. Extracts of many medicinal plants and seaweeds have been documented to possess anti-diabetic properties. A brown alga, S. tenerrimum, found on the west coast of India, is chosen in this study to analyse the anti-diabetic property of its methanolic extract. This extract was used to treat streptozotocin-induced diabetic mice. An experimental design was framed based on acute toxicity studies to determine the change in blood glucose level, body weight, lipid profile, liver enzymes (SGPT and SGOT) and the renal function markers (urea and creatinine). After 15 days of treatment, an increase in body weight and HDL cholesterol was observed while the total cholesterol, VLDL, LDL, serum triglyceride, SGOT, SGPT, creatinine and urea decreased with $250 \mathrm{mg} / \mathrm{Kg} . \mathrm{bw}$ of $S$. tenerrimum methanolic extract in Streptozotocin-induced diabetic mice group. This difference is significant $(p<0.05)$ when compared with a healthy non-diabetic mice group and a treated diabetic mice group. This proves that the methanolic extract of $S$. tenerrimum possess anti-diabetic property. Further research could explore the active compounds that can be used in the formulation of herbal medicine for diabetes mellitus.
\end{abstract}

Keywords: Diabetes mellitus, Streptozotocin, diabetic mice, S. tenerrimum

\section{INTRODUCTION}

Diabetes is the upcoming jeopardy of human health that instils owing to deficiency in insulin secretion or action. ${ }^{1}$ This disease is directly related to the impairment of eyesight, damage and dysfunction of kidney, liver and heart and nerves. The acute impact of diabetes is also reflected via periodontitis and impaired immune response. ${ }^{2}$ Globally, millions of people are affected by diabetes mellitus. Indians are more prone to this disease wherein genetic inheritance of diabetes mellitus is also a major factor. Anticipation by WHO (World Health Organization) reports that the cases of diabetes mellitus in India would reach 74 million $2025 .^{3}$

An estimate by WHO states that 366 million people worldwide will be the victims of diabetes mellitus by $2030 .{ }^{4}$ International Diabetic Federation ${ }^{5}$ reported that around 642 million people would suffer from diabetes by 2040 . Pandey and Sharma ${ }^{6}$ reported that India, an emerging diabetic hotspot might possibly contain 69.9 million diabetic victims by 2025 . It could also rise to 80 million by 2030 . Type 1 diabetes mellitus, commonly known as insulin-dependent diabetes mellitus (IDDM), is a chronic autoimmune illness in which the pancreatic cells are destroyed abruptly, resulting in insulin shortage. Type 2 diabetes mellitus, also known as non-insulin-dependent diabetes mellitus (NIDDM), is caused by a decrease in insulin sensitivity in target tissues, which can occur alongside insulin resistance. ${ }^{7}$ Type 2 diabetes has more complications than type 1 diabetes and is also emerging as an epidemic disease in some countries ${ }^{8}$ owing to the the short and long term effect on human health. Survey documents about 1 in 11 adults suffer from diabetes mellitus out of which $90 \%$ of the people suffer from type 2 diabetes mellitus. ${ }^{9}$ The complications of diabetes mellitus can be dealt through lifestyle changes, diet and exercise. Treatment involves regular intake of oral medication and sometimes insulin injection under critical conditions. ${ }^{10}$

Seaweed or macroalgae are the floral inhabitants in marine or brackish water environments. Various seaweeds were reported to possess antidiabetic property. Seaweeds such as Undaria pinnatifida sporophyll (UPS), Codium fragile (CF), and Gracilaria verrucosa (GV) possess antidiabetic property. Water extract of these seaweeds were documented for their role in inhibiting excess glucose absorption as well as 
the utilization of excess glucose in other cellular pathways thus diverting the excess glucose from entering the blood stream. ${ }^{11}$ Several other red, green and brown seaweeds were also reported to possess antidiabetic property. Brown seaweeds are known for their bioactive compounds especially phlorotannins which were found to inhibit the enzymes responsible for hyperglycemia. ${ }^{12}$ An investigation by Unnikrishnan et al. ${ }^{13}$ stated that the metabolic enzymes involved in hyperglycemic activity were inhibited by the petroleum ether, ethyl acetate and methanolic extracts of the brown seaweeds Sargassum polycystum and Sargassum wightii. The laminarian and fucoidan fractions of brown seaweeds (Sargassum duplicatum and Turbinaria decurens) were also reported to possess antidiabetic property. ${ }^{14}$ Moreover, several species of Sargassum such as S. wightii, S. oligocystum, S. hystrix and $S$. angustifolium were repoted to possess antidiabetic property. ${ }^{15-18} S$. tenerrimum is a brown algae found on the west coast of India and it is known for its bioactive compounds. The extracts of this seaweed has been reported to possess antimicrobial activity, especially against pathogenic microorganisms owing to the presence of phenols. These phenolic compounds tend to increase the commercial value of seaweeds in the food and pharma industry..$^{19}$ Upon investigation, the ethanolic extract of this seaweed was found to possess antioxidant and antitumor activity. ${ }^{20}$ Fucoidan of $S$. tenerrimum also possess antiviral activity against herpes simplex virus. ${ }^{21}$ Due to the therapeutic applications of $S$. tenerrimum, this seaweed was chosen to study its antidiabetic property. A natural compound, Streptozotocin (STZ), used in this study induces diabetes mellitus in experimental animals owing to its toxic nature against the $\beta$-cells of pancreas that produce insulin. ${ }^{22}$ Using streptozotocin-induced diabetic mice, this study examines the anti-diabetic efficacy of methanolic extract of $S$. tenerrimum.

\section{MATERIALS AND METHODS \\ Materials used}

All the reagents used in this study were analytical grade and obtained from Qualigens, India. Blood based functions test were done using Span Diagnostics, Surat, India.

\section{Sample Collection}

The selected alga was identified as $S$. tenerrimum which belongs to the order Fucales and division Phaeophyta. It was identified at Conservation of Coastal and Marine Resources Division, Anna University Campus, Chennai by Dr. V. Deepak Samuel. This alga is a brown alga collected from the littoral region of the Mandapam coast $\left(9^{\circ} 16^{\prime} 32.6^{\prime \prime} \mathrm{N} 79^{\circ} 07^{\prime} 25.0^{\prime \prime} \mathrm{E}\right)$ of the Gulf of Mannar which is located on the southeast coast of India. After a thorough cleaning, the epiphytes and necrotic parts of the macro algae were removed to score out the impurities.

\section{Preparation of the extract}

The soxhlet extraction protocol was followed to prepare the methanolic extract from shade dried S. tenerrimum. About $20 \mathrm{mg}$ of the algal powder was packed and placed in the Soxhlet's apparatus to which $250 \mathrm{ml}$ of methanol was added afterwards. The extract was allowed to evaporate such that the solvent gets removed in a rotary evaporator and then the extract was collected and stored for further use.

\section{Experimental Animal}

Experimental animals, ie., Albino mice (Pasteur Institute, Breeding section, Coonoor) each weighing 25 to $30 \mathrm{~g}$ were selected and housed in a suitable environmental condition with proper temperature monitor and control with 12 hours of light and dark conditions. Standard nutrition was provided in the form of pellets (Sai Feeds, Mumbai, India) along with a required quantity of water. These experimental animals were allowed to acclimatize to the laboratory conditions atleast 24 hours before the experimental procedure. All of the tests were carried out in strict accordance with the Animal Ethics Committee of the Government of India's guidelines and regulations. The experimental animals' ethical clearance number is IAEC/KU/BT/14/15.

\section{Acute Toxicity Studies}

Following the guidelines of CPCSEA OECD guidelines, an acute toxicity study was conducted in all the experimental animals. The mice were divided into three groups with three animals in each group, each at a fixed dosage level of the methanolic extract of $S$. tenerrimum at 100, 250 and $500 \mathrm{mg} / \mathrm{kg}$. bw respectively. These animals were analyzed for abrupt modifications in the appearance of the skin, fur density, eyesight, mucous membrane, behavioural changes, sleep cycle, coma and death. ${ }^{23,24}$ After a physical 
examination, the group that got $250 \mathrm{mg} / \mathrm{kg}$.bw of methanolic extract of $S$. tenerrimum was chosen for future research because it showed no signs of toxicity during the investigation. ${ }^{25}$

\section{Experimental Design}

Streptozotocin at a concentration of $50 \mathrm{mg} / \mathrm{kg}$ was induced into the experimental hyperglycemic animals as mentioned in Vasconcelos et al. ${ }^{26}$ The experimental animals were divided into four groups with three animals in each group. Group I contained normal healthy mice while the second group is a diabetic group that was left untreated with streptozotocin dosage. Streptozotocin and glibenclamide $(10 \mathrm{mg} /$ $\mathrm{kg} . \mathrm{bw})$ were given to the third group. Though the efficacy of glibenclamide is inferior to metformin, treatment failure was observed in metformin dosages. A combination of metformin and insulin was efficient rather than metformin alone in patients suffering from gestational diabetes. Therefore, glibenclamide was chosen for this study. ${ }^{27}$ As a positive control, this group was used. The fourth group is the diabetic group that was given streptozotocin and methanolic extract of $S$. tenerrimum at a dose of $250 \mathrm{mg} / \mathrm{kg}$.bw (two more groups could have been added; a vehicle control and extract alone treated group).

\section{Blood Samples collection}

Blood was drained out through the tail tip of experimental animals for every 7 days. After an overnight fasting, the mice in study groups were sacrificed with a proper dosage of anaesthetics. Blood was collected once the mice were subjected to cardiac puncture through the artery using a sterile syringe. Centrifugation was done to remove the impurities and the supernatant was stored for biochemical analysis at $-20^{\circ} \mathrm{C} .{ }^{28}$

\section{Bodyweight estimation}

The bodyweight of the treatment groups was monitored periodically under proper nutritious conditions. Bodyweight of all the groups was noted every 7 days and the weight change was compared between the $0^{\text {th }}$ and $15^{\text {th }}$ day. This protocol was adapted from Draganescu et al..$^{29}$

Biochemical analysis

\section{Blood Glucose estimation}

On the $0^{\text {th }}, 7^{\text {th }}$, and $15^{\text {th }}$ days of the trial, blood glucose levels were measured, and body weight measurements were done on the $0^{\text {th }}$ and $15^{\text {th }}$ day of the study. The method followed by Geetha. ${ }^{30}$ was adopted to estimate glucose in this study. A glucose standard at a known concentration was used to determine the amount of glucose in the samples. At an absorbance of 620 $\mathrm{nm}$, the final green colour solution developed was read and the amount of glucose was estimated graphically.

Determination of the effect of S. tenerrimum extract on Lipid Profile

Diabetes specifically affects the lipid profile. Therefore, the amount of LDL, total cholesterol, VLDL, HDL and serum triglyceride in all the groups were determined as per the method followed by Muneer and Rabbani. ${ }^{31}$ and Seedevi et al. ${ }^{32}$

Determination of the effect of $S$. tenerrimum extract on Liver Enzyme levels (SGPT \& SGOT) Span Diagnostics

Serum Glutamic Pyruvic Transaminase (SGPT) and Serum Glutamic Oxaloacetic Transaminase (SGOT) activity determine the infection of diabetes over liver enzymes. Using adiagnostic kit to check SGPT and SGOT activity (Span Diagnostics, Surat, India), the activity of these enzymes was measured at an absorbance of $505 \mathrm{~nm}$. Standard sodium pyruvate (2mM) was used to plot the calibration curve. From this standard plot, the activity of SGPT and SGOT were calculated in IU/ml. ${ }^{33}$ This can be converted to IU/L. Determination of the effect of $S$. tenerrimum extract on Renal Enzyme levels- estimation of urea and creatinine

Kidney function is abruptly affected in diabetic patients which under chronic conditions would result in kidney failure. Monitoring of urea and creatinine is essential to maintain a properly balanced medication. Therefore, serum urea and creatinine levels in the determined four study groups were estimated by the protocol mentioned in Basavarajappa et al. ${ }^{34}$

\section{Statistical Analysis}

Data are expressed in terms of mean \pm standard deviation. Differences among treatment group means were assessed by analysis of variance with Duncan's Multiple Range Test (DMRT) and group means were considered to be significantly different at $p<0.05$.

\section{RESULTS AND DISCUSSION}

Diabetes Mellitus comprise various 
metabolic disorders which are characterized by high glucose levels with long-term effects that abruptly damage the functioning of many organs. Acute effects include blurred vision, excess urination, nerve weakness, excessive hunger and thirst, muscle cramps and weight loss while the chronic condition results in organ failure. ${ }^{35,36}$ Although several hypoglycemic agents are available, the side effects are still a threat. ${ }^{37}$

\section{S. tenerrimum extract on Body Weight of STZ- Induced Diabetic Mice}

Reduction in body weight is a significant symptom of diabetes mellitus. The result of degeneration of adipose and muscle tissue onsets an energy demand due to the excess conversion of glycogen to glucose and frequent urination. Therefore, bodyweight of the experimental mice was observed periodically. Increased bodyweight of the treated group (Streptozotocin and methanolic extract of $S$. tenerrimum) was observed on the $15^{\text {th }}$ day compared to the other three groups. ${ }^{38}$ The methanolic extract of (Lamiaceae) leaves was used to test the anti-diabetic efficacy of alloxaninduced diabetic mice. After inducing two dosage levels ( 250 and $500 \mathrm{mg} / \mathrm{kg}$ body weight) of the methanolic extract, a weight change was noticed

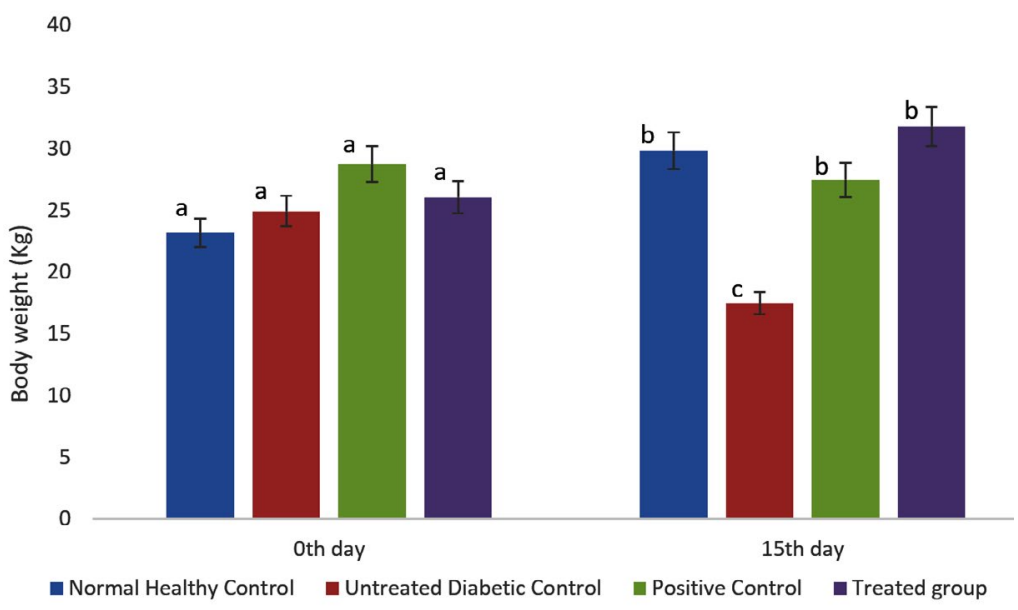

Fig. 1. S. tenerrimum extract on Body Weight of STZ-Induced Diabetic Mice.

Values are mean \pm S.D for 6 mice in each group. Bar is not sharing an alphabet implies significant difference at $\mathrm{p}<0.05$ (DMRT)

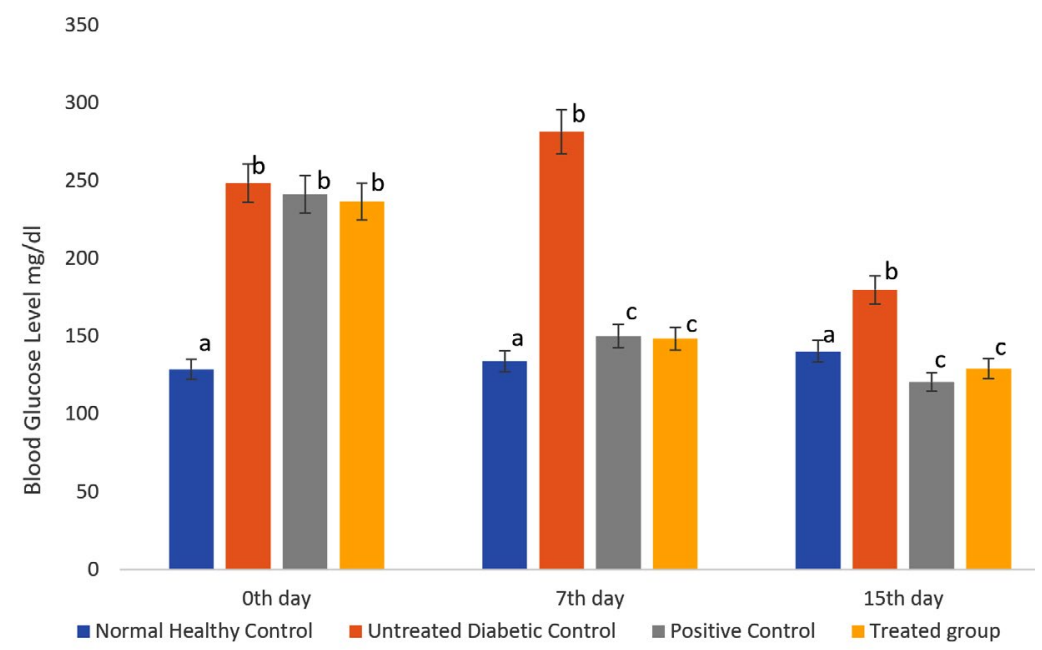

Fig. 2. S. tenerrimum Extract on Fasting Blood Glucose Level of STZ-Induced Diabetic Mice.

Values are mean \pm S.D for 6 mice in each group. Bar is not sharing an alphabet implies significant difference at $\mathrm{p}<0.05$ (DMRT) 
regularly. An increase in body weight was observed significantly which proves that the methanolic extract has the antidiabetic property. Similarly, in this study, a decline in weight loss was observed on the $15^{\text {th }}$ day (Fig. 1). This indicates that the methanolic extract of the selected seaweed has the potential to lessen the intensity of diabetes mellitus in streptozotocin-induced mice.

Diabetes mellitus is characterized by many side effects and one among them is hyperglycemia. The treatment group's blood glucose level decreased as a result of the efficacy of the methanolic extract of $S$. tenerrimum. Hydromethanolic leaf extract of Calpurnia aurea was investigated for its anti-diabetic property by Belayneh and Birru. ${ }^{39}$ They reported that the treated group documented a decrease in blood glucose level after receiving the hydromethanolic extract. This result was also observed in the proposed study which further clarifies the anti-diabetic property of methanolic extract of $S$. tenerrimum (Fig. 2).

Determination of the effect of $S$. tenerrimum extract on Lipid Profile of STZ-Induced Diabetic Mice

The study of lipid profile of the diabetic mice shows the variation in the amount of total cholesterol, LDL, VLDL, HDL and serum triglyceride. The complications in the cardiovascular system can be identified when a variation in lipid profile is observed. It could also result in cardiac arrest due to the deposition of excess cholesterol in blood vessels. In this study, the treated group saw a significant reduction in total cholesterol, LDLcholesterol, VLDL-cholesterol, and triglycerides, as well as an increase in HDL-cholesterol (Fig. 3). Administration of S. tenerrimum methanolic extract significantly reduced total cholesterol, LDLCholesterol, VLDL-Cholesterol and triglyceride while the good cholesterol, ie., HDL-cholesterol level increased which is a positive indication of anti-diabetic activity. Owolabi et al., ${ }^{40}$ reported the observed change in lipid profile of this study in Alloxan-Induced diabetic rats treated with the methanolic leaf extract of Napoleona vogelii (Lecythidaceae) hook and planch. It is known from this study that diabetes adversely affects lipid metabolism and hence the methanolic extract of the seaweed ( $S$. tenerrimum) could be a better source to balance the lipid profile.

The amount of serum cholesterol was determined to be less in the treated group than the amount in the untreated group. When comparing the untreated diabetes control group (229 mg/ dl) to the normal healthy control group (41.33 $\mathrm{mg} / \mathrm{dl}$ ), the current findings revealed that the level of blood total cholesterol was considerably higher in the untreated diabetic control group $(229 \mathrm{mg} / \mathrm{dl})$. The change in lipid metabolism was demonstrated by a decrease in total cholesterol level (ie, $145.66 \mathrm{mg} / \mathrm{dl}$ ) after supplementation with $S$. tenerrimum extract. The evaluation of antidiabetic and antihyperlipidemic property of hydroalcoholic extract from the seeds of Peganum

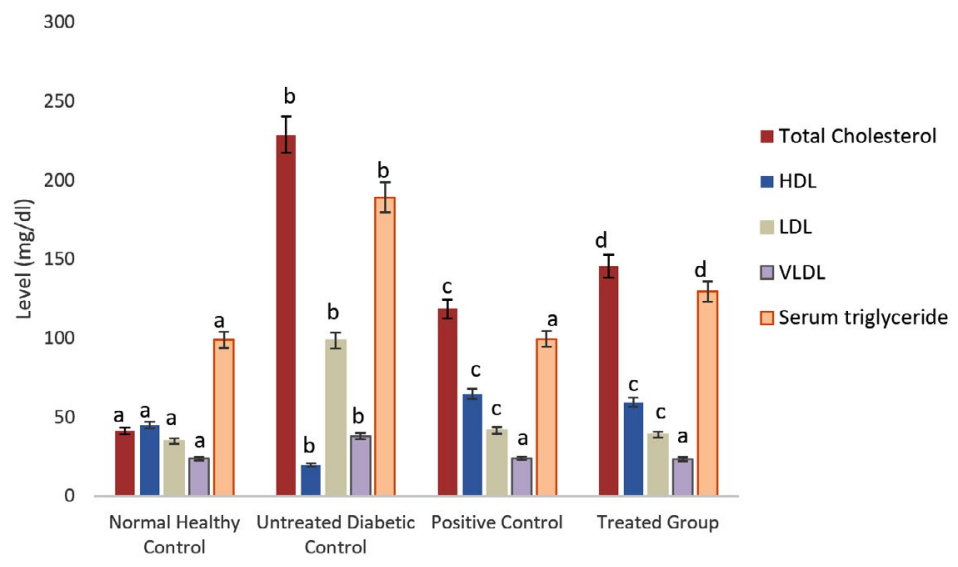

Fig.3. S. tenerrimum extract on lipid profile of STZ-Induced Diabetic Mice.

Values are mean $\pm S$.D for 6 mice in each group. Bar is not sharing an alphabet implies significant difference at $\mathrm{p}<0.05$ (DMRT). 
harmala in STZ-induced diabetic male rats by Komeili et al. ${ }^{41}$ documented a decrease in total cholesterol level in the treated group compared with the untreated diabetic group. Similarly, Kifle and Belayneh ${ }^{42}$ found that increasing doses of crude hydromethanol extract of Hagenia abyssinica (Rosaceae) leaves (100, 200, and 400 $\mathrm{mg} / \mathrm{kg}$ ) resulted in a significant reduction in total cholesterol levels in streptozotocin-induced diabetic mice. These studies prove that the total cholesterol level in diabetic mice/rats can be derailed upon treatment with alcoholic extracts which is also a result of this research. When compared to the untreated diabetic group (LDL= $98.67 \pm 1.53 \mathrm{mg} / \mathrm{dl} ; \mathrm{VLDL}=38 \pm 1 \mathrm{mg} / \mathrm{dl}$ ), reduction in the concentration of LDL and VLDL-cholesterol $(L D L=39 \pm 1 \mathrm{mg} / \mathrm{dl} ; \mathrm{VLDL}=23.33 \pm 1.53 \mathrm{mg} / \mathrm{dl})$ in the diabetic group treated with methanolic extract of S. tenerrimum was noticed in this study. Komeili et al., ${ }^{41}$ and Kifle and Belayneh ${ }^{42}$ also reported a decrease in cholesterol, VLDL and LDL evels in alcoholic extract-treated STZ-induced treated group (mice/rat).

In streptozotocin-induced diabetic rats, an ethanolic extract of the seaweed $S$. polystum $(150 \mathrm{mg} / \mathrm{kg})$ raised HDL cholesterol levels. ${ }^{43}$ AlFaris

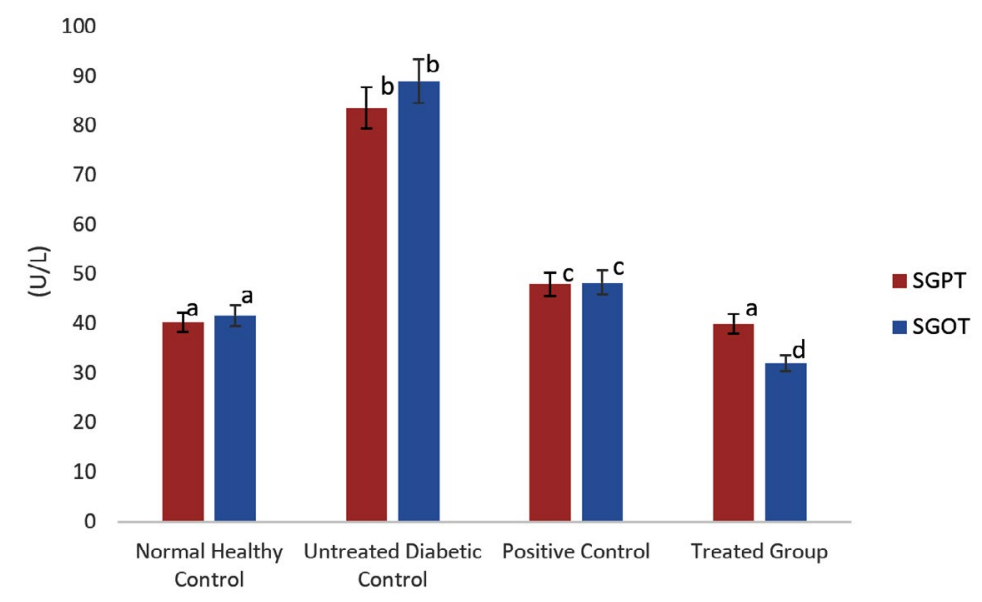

Fig. 4. S. tenerrimum extract on serum GPT and GOT of STZ-Induced Diabetic Mice.

Values are mean $\pm S$.D for 6 mice in each group. Bar is not sharing an alphabet implies significant difference at $\mathrm{p}<0.05$ (DMRT)

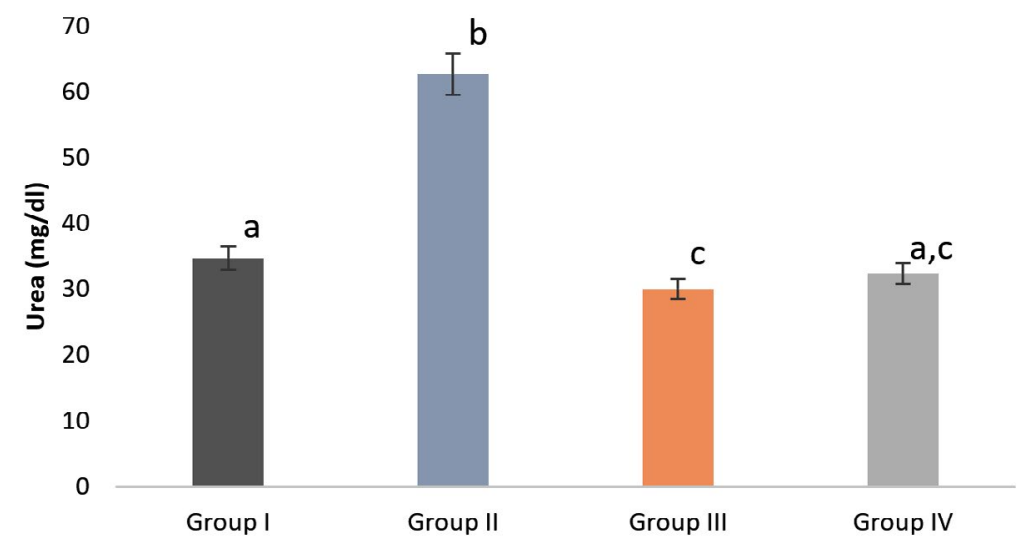

Fig. 5. S. tenerrimum extract on Serum Urea level of STZ-Induced Diabetic Mice.

Values are mean $\pm S$.D for 6 mice in each group. Bar is not sharing an alphabet implies significant difference at $\mathrm{p}<0.05$ (DMRT). 
et al. ${ }^{44}$ found that the methanolic extract of Duvalia corderoyi increased HDL cholesterol levels in streptozotocin-induced diabetic rats. A similar result was observed in this study when the treated group $(59.33 \pm 1.15 \mathrm{mg} / \mathrm{dl})$ is compared with the untreated diabetic control mice $(19.67 \pm 0.58 \mathrm{mg} /$ dl). The amount of serum triglycerides is the major determinant of diabetes mellitus. A decreased amount of serum triglyceride was observed in the treated group in this proposed study i.e., $129.67 \pm 2.08 \mathrm{mg} / \mathrm{dl}$ after the administration of methanolic extract of $S$. tenerrimum. Murugesan et al. ${ }^{45}$ observed the anti-diabetic efficacy of the methanolic extract of the seaweed (Spatoglossum asperum) in alloxan-induced Wistar albino rats. They observed a reduction in triglyceride levels in the treated group. Worthwhile, Oliyaei et al., ${ }^{18}$ reported a decrease in triglyceride levels in streptozotocin-nicotinamide-induced type 2 diabetic mice treated with the ethanolic extract of the pigment fucoxanthin (encapsulated) present in the brown seaweed S. angustifolium. It is also observed through several studies that the pigments present in the methanolic extract of seaweed or any plant source are responsible for the increase or decrease in the evaluated antidiabetic params. ${ }^{46}$

Determination of the effect of $S$. tenerrimum on Liver Enzyme Levels of Streptozotocin-Induced Diabetic Mice

The liver is a primary target of diabetes mellitus, hence determining the level of enzymes present in the treated mice group is critical. The major indicator enzymes of liver function are serum glutamate-pyruvate transaminase (SGPT) and serum glutamate-oxaloacetate transaminase (SGOT). An elevation in the level of these enzymes is a signal of cellular leakage that occurs on account of cell membrane dysfunction thus leading to liver damage in diabetic patients. In this study, treatment with the methanolic extract of $S$. tenerrimum abruptly reduced the level of SGPT and SGOT enzymes than in the healthy control and untreated group (Fig. 4). This result was already documented by Ramachandran et al., ${ }^{47}$ in an investigation of anti-diabetic property of the aqueous extract of Terminalia paniculata bark in streptozotocin-induced diabetic rats. Moreover, the ethanolic extract of the brown seaweed $S$. longiotom and the methanolic extract of the sub-littoral seagrass Halodule uninervis in alloxaninduced diabetic rats and streptozotocin-induced diabetic mice reduced the level of SGPT and SGOT respectively. ${ }^{48,49}$ These studies are a proof that the hepatic damage in diabetic mice can be treated effectively.

Determination of the effect of S. tenerrimum on Serum Urea and Creatinine Levels to access the kidney Function of Streptozotocin-Induced Diabetic Mice

Diabetic mice had elevated plasma urea and creatinine levels, which is a common symptom. In diabetic individuals, urea and creatinine levels are important indicators of renal

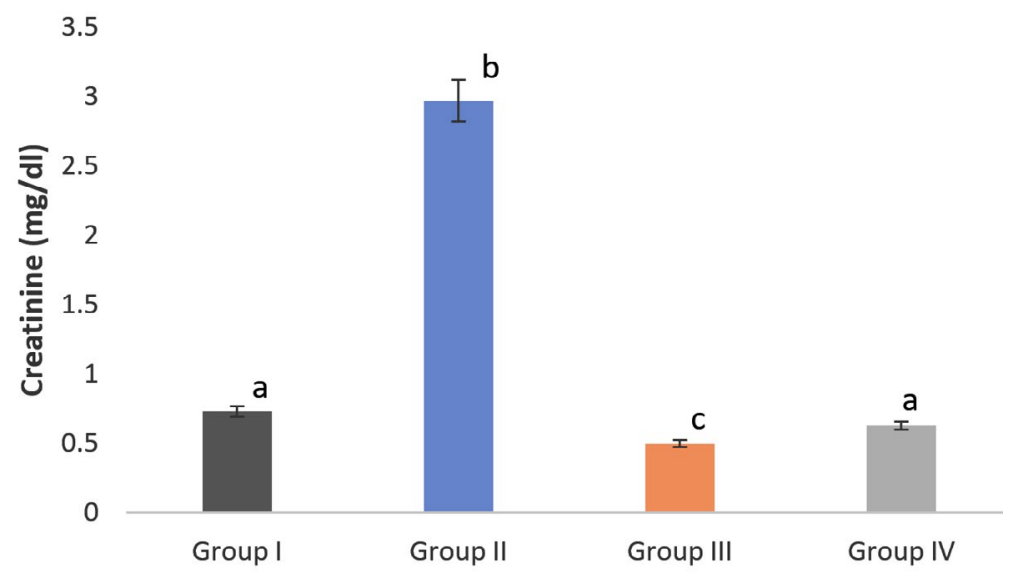

Fig. 6. S. tenerrimum extract on Serum Creatinine level of STZ-Induced Diabetic Mice.

Values are mean $\pm S$.D for 6 mice in each group. Bar is not sharing an alphabet implies significant difference at $\mathrm{p}<0.05$ (DMRT) 
impairment. In this study, the methanolic extract of $S$. tenerrimum was used to treat streptozotocininduced diabetic mice, which resulted in a decrease in urea and creatinine levels.(Fig. 5 \& $6)$. An increase in kidney metabolism elevates urea and creatinine level. After the administration of the algal polysaccharide of Enteromorpha intestinalis, Moustafa et al., ${ }^{50}$ observed a similar decrease in urea and creatinine levels in diabetic rats. Renitta et al., ${ }^{25}$ also reported the same result in streptozotocin-induced diabetic mice treated with the methanolic extract of $S$. wightii.

\section{CONCLUSION}

This research highlights the efficacy of the brown seaweed, $S$. tenerrimum utilization in pharmacology. Based on the results observed, it is inferred that methanolic extract of this seaweed can be administered as a potent anti-diabetic medication in humans. Rather than the intake of metformin, glibenclamide or insulin, intake of methanolic extract is a biological strategy to control diabetes mellitus. A thorough investigation on in vitro studies could instigate legal approval towards the application of this research for the treatment of diabetic patients. Due to the low capital investment, this medication affordable by all class of working community. Other pharmacological properties such as antimicrobial, antioxidant property of several species of Sargassum highlights that seaweeds possess commendable therapeutic effects on human health.

\section{ACKNOWLEDGMENTS}

None.

\section{CONFLICT OF INTEREST}

The authors declare that there is no conflict of interest.

\section{FUNDING}

None.

\section{AUTHORS' CONTRIBUTION}

All authors listed have made a substantial, direct and intellectual contribution to the work, and approved it for publication.

\section{DATA AVAILABILITY}

All datasets generated or analyzed during this study are included in the manuscript.

\section{ETHICS STATEMENT}

Not applicable.

\section{REFERENCES}

1. Casqueiro J, Casqueiro J, Alves C. Infections in patients with diabetes mellitus: A review of pathogenesis. Indian J Endocrinol Metab. 2012;16(Suppl 1):S27-36. doi: $10.4103 / 2230-8210.94253$

2. Balaji R, Duraisamy R, Kumar MPS. Complications of diabetes mellitus: A review. Drug Invent Today. 2019;12(1):98-103.

3. Prajapati DM, Patel NM, Savadi RV, Akki KS, Mruthunjaya K. Alleviation of alloxan-induced diabetes and its complications in rats by Actinodaphne hookeri leaf extract. Bangladesh J Pharmacol. 2008;3(2):102106. doi: 10.3329/bjp.v3i2.946

4. Wild S, Roglic G, Green A, Sicree R, King H. Global Prevalence of Diabetes: Estimates for the year 2000 and projections for 2030. Diabetes Care. 2004;27(5):10471053. doi: 10.2337/diacare.27.5.1047

5. IDF. International Diabetes Federation (IDF) Diabetes Atlas. $7^{\text {th }}$ ed.; 2015. https://diabetesatlas.org/upload/ resources/previous/files/7/IDF\%20Diabetes\%20 Atlas\%207th.pdf.

6. Pandey S, Sharma V. World diabetes day 2018: Battling the Emerging Epidemic of Diabetic Retinopathy. Indian J Ophthalmol. 2018;66(11):1652-1653. doi: 10.4103/ ijo.ijo_1681_18

7. Ozougwu JC, Obimba KC, Belonwu CD, Unakalamba $\mathrm{CB}$. The pathogenesis and pathophysiology of type 1 and type 2 diabetes mellitus. J Physiol Pathophysiol. 2013;4(4):46-57. doi: 10.5897/jpap2013.0001

8. Olokoba AB, Obateru OA, Olokoba LB. Type 2 Diabetes Mellitus: A Review of Current Trends. Oman Med J. 2012;27(4):269-273. doi: 10.5001/omj.2012.68

9. Zheng $\mathrm{Y}$, Ley SH, Hu FB. Global aetiology and epidemiology of type 2 diabetes mellitus and its complications. Nat Rev Endocrinol. 2017;14(2):88-98. doi: 10.1038/nrendo.2017.151

10. Colberg SR, Sigal RJ, Fernhall B, et al. Exercise and type 2 diabetes. Diabetes Care. 2010;33(12):147-167. doi: $10.2337 /$ dc10-9990

11. Kim E, Cui J, Kang I, Zhang G, Lee Y. Potential Antidiabetic Effects of Seaweed Extracts by Upregulating Glucose Utilization and Alleviating Inflammation in C2C12 Myotubes. Int J Environ Res Public Health. 2021;18(3):1367. doi: 10.3390/ijerph18031367

12. Gunathilaka TL, Samarakoon K, Ranasinghe P, Peiris LDC. Antidiabetic Potential of Marine Brown Algae-a Mini Review. J Diabetes Res. 2020;2020:1230218. doi: 10.1155/2020/1230218

13. Unnikrishnan PS, Suthindhiran K, Jayasri MA. Antidiabetic potential of marine algae by inhibiting key metabolic enzymes. Front Life Sci. 2015;8(2):148-159. 


\section{doi: $10.1080 / 21553769.2015 .1005244$}

14. Hardoko, Siratantri T, Eveline, Yogabuana M, Olivia S, An In Vitro Study of Antidiabetic Activity of Sargassum duplicatum and Turbinaria decurens Seaweed. Int J Pharm Sci Invent. 2014;3:13-18.

15. Mohapatra L, Bhattamishra SK, Panigrahy R, Parida $\mathrm{S}$, Pati P. Antidiabetic Effect of Sargassum wightii and Ulva fasciata in High Fat Diet and Multi Low Dose Streptozotocin Induced Type 2 Diabetic Mice. UK J Pharm Biosci. 2016;4(2):13-23. doi: 10.20510/ukjpb/4/ i2/97081

16. Akbarzadeh $\mathrm{S}$, Gholampour $\mathrm{H}$, Farzadinia $\mathrm{P}$, et al. Anti-diabetic effects of Sargassum oligocystum on Streptozotocin- induced diabetic rat. Iranian J Bas Med Sci. 2018;21(3):342-346.

17. Gotama TL, Husni A, Ustadi. Antidiabetic Activity of Sargassum hystrix Extracts in Streptozotocin-Induced Diabetic Rats. Prev Nutr Food Sci. 2018;23(3):189-195. doi: 10.3746/pnf.2018.23.3.189

18. Oliyaei N, Moosavi-Nasab M, Tamaddon AM, Tanideh $N$. Antidiabetic effect of fucoxanthin extracted from Sargassum angustifolium on streptozotocinnicotinamide-induced type 2 diabetic mice. Food Sci Nutr. 2021;9:3521-3529. doi: 10.1002/fsn3.2301

19. Shitole SS, Balange AK, Gangan SS. Use of Seaweed (Sargassum tenerrimum) extract as gel enhancer for lesser sardine (Sardinella brachiosoma) surimi. Int Aquat Res. 2014;6(1):45. doi: 10.1007/s40071-0140055-9

20. Patra S, Muthuraman MS, Prabhu ATJR, Priyadharshini RR, Parthiban S. Evaluation of Antitumor and Antioxidant Activity of Sargassum tenerrimum against Ehrlich Ascites Carcinoma in Mice. Asian Pac J Cancer Prev. 2015;16(3):915-921. doi: 10.7314/ apjcp.2015.16.3.915

21. Yende SR, Harle UN, Chaugule BB. Therapeutic potential and health benefits of Sargassum species. Pharmacogn Rev. 2014;8(15):1-7. https://doi. org/10.4103/0973-7847.125514

22. Abdollahi M, Hosseini A. Streptozotocin. Encyclopedia Toxicol. 2014:402-404. doi: 10.1016/b978-0-12386454-3.01170-2

23. Jayaprasad B, Sharavanan PS, Sivaraj R. Acute Toxicity and Dose Fixation Studies on Chloroxylon swietenia Dc Bark Extracts on Streptozotocin-induced Diabetic Rats. Int Lett Nat Sci. 2015;48:8-13. doi: 10.18052/ www.scipress.com/ilns. 48.8

24. Lira SM, Canabrava NV, Benjamin SR, et al. Evaluation of the toxicity and hypoglycemic effect of the aqueous extracts of Cnidoscolus quercifolius Pohl. Braz J Med Biol Res. 2017;50(10):e6361. https://doi. org/10.1590/1414-431×20176361

25. Renitta RE, Narayanan R, Cypriyana PJJ, Samrot AV. Antidiabetic potential of methanolic extracts of Sargassum wightii in streptozotocin-induced diabetic mice. Biocatal Agric Biotechnol. 2020;28:101763. doi: 10.1016/j.bcab.2020.101763

26. Vasconcelos CFB, Maranhao HML, Batista TM, et al. Hypoglycaemic activity and molecular mechanisms of Caesalpinia ferrea Martius bark extract on streptozotocin-induced diabetes in Wistar rats. J Ethnopharmacol. 2011;137(3):1533-1541. doi: 10.1016/j.jep.2011.08.059

27. Balsells M, Garcia-Patterson A, Sola I, Roque M, Gich I, Corcoy R. Glibenclamide, metformin, and insulin for the treatment of gestational diabetes: a systematic review and meta-analysis. BMJ Clin Res. 2015;350:1-6. doi: 10.1136/bmj.h102

28. Bari MW, Islam MM, Khatun M, et al. Antidiabetic effect of Wedelia chinensis leaf extract in alloxan induced Swiss albino diabetic mice. Clin Phytosci. 2020;6(1):58. doi: 10.1186/s40816-020-00197-6

29. Draganescu D, Andritoiu C, Hritcu D, Dodi G, Popa MI. Flaxseed Lignans and Polyphenols Enhanced Activity in Streptozotocin-Induced Diabetic Rats. Biology. 2021;10(1):43. doi: 10.3390/biology10010043

30. Geetha K. Antidiabetic activity of Achyranthes aspera L. with alloxanised mice for the estimation of level of glucose and cholesterol. Asian J Plant Sci Res. 2016;6(2):18-23.

31. Muneer A, Rabbani SI. Protective Effect of Terminalia chebula Extract in Doxorubicin Induced Hyperlipidemic Rats. J Adv Med Med Res. 2019;30:1-9. doi: 10.9734/ jammr/2019/v30i1130275

32. Seedevi P, Ganesan AR, Moovendhan M, et al. Anti-diabetic activity of crude polysaccharide and rhamnose-enriched polysaccharide from $G$. lithophila on Streptozotocin (STZ)-induced in Wistar rats. Sci Rep. 2020;10(1):556. doi: 10.1038/s41598-020-57486-w

33. Karan SK, Mondal A, Mishra SK, Pal D, Rout KK. Antidiabetic effect of Streblus asper in streptozotocininduced diabetic rats. Pharm Biol. 2013;51(3):369-375. doi: 10.3109/13880209.2012.730531

34. Basavarajappa GM, Nanjundan PK, Alabdulsalam A, et al. Improved Renoprotection in Diabetes with Combination Therapy of Coccinia indica Leaf Extract and Low-Dose Pioglitazone. Separations. 2020;7(4):58. doi: $10.3390 /$ separations 7040058

35. Tripathi BK, Srivastava AK. Diabetes mellitus: Complications and therapeutics. Med Sci Monit. 2006;12(7):130-147.

36. Abutaleb MH. Diabetes mellitus: an overview. Pharm Pharmacol Int J. 2016;4(5):406-411. doi: 10.15406/ ppij.2016.04.00087

37. Lorenzati B, Zucco C, Miglietta S, Lamberti F, Bruno G. Oral Hypoglycemic Drugs: Pathophysiological Basis of Their Mechanism of Action. Pharmaceuticals. 2010;3(9):3005-3020. doi: 10.3390/ph3093005

38. Taye GM, Bule M, Gadisa DA, Teka F, Abula T. In vivo Antidiabetic Activity Evaluation of Aqueous and $80 \%$ Methanolic Extracts of Leaves of Thymus schimperi (Lamiaceae) in Alloxan-induced Diabetic Mice. Diabetes Metab Syndr Obes Targets Ther. 2020;13:3205-3212. doi: 10.2147/dmso.s268689

39. Belayneh YM, Birru EM. Antidiabetic Activities of Hydromethanolic Leaf Extract of Calpurnia aurea (Ait.) Benth. Subspecies aurea (Fabaceae) in Mice. Evid Based Compl Alt Med. 2018;2018:3509073. doi: 10.1155/2018/3509073

40. Owolabi O, Inninh S, Anaka O, Iyamu O. Antidiabetic and hypolipidemic effects of methanol leaf extract of Napoleona vogelii (Lecythidaceae) Hook \& Planch on alloxan-induced diabetes mellitus in rats. Trop $J$ Pharm Res. 2014;13(11):1903-1909. doi: 10.4314/tjpr. 


\section{v13i11.19}

41. Komeili G, Hashemi M, Bameri-Niafar M. Evaluation of Antidiabetic and Antihyperlipidemic Effects of Peganum harmala Seeds in Diabetic Rats. Cholesterol. 2016;2016:7389864. doi: 10.1155/2016/7389864

42. Kifle ZS, Belayneh YM. Antidiabetic and Antihyperlipidemic Effects of the Crude Hydromethanol Extract of Hagenia abyssinica (Rosaceae) Leaves in Streptozotocin-Induced Diabetic Mice. Diabetes Metab Syndr Obes Targets Ther. 2020;13:4085-4094. doi: 10.2147/dmso.s279475

43. Husni A, Purwanti D, Ustadi. Blood Glucose Level and Lipid Profile of Streptozotocin-induced Diabetes Rats Treated with Sodium Alginate from S. crassifolium. J. Biol. Sci. 2016;16:58-64. doi: 10.3923/jbs.2016.58.64

44. AlFaris NA, Alshammari GM, Alsayadi MM, AlFaris MA, Yahya MA. Antidiabetic and antihyperlipidemic effect of Duvalia corderoyi in rats with streptozotocininduced diabetes. Saudi J Biol Sci. 2020;27(3):925-934. doi: 10.1016/j.sjbs.2020.01.024

45. Murugesan S, Pandithurai M, Krithika N, Sivamurugan V. Evaluation of Antidiabetic Efficacy of Brown Alga Spatoglossum asperum J. Agardh by Alloxan Stimulated Hyperglycemia on Wistar Albino Rats. Int J Pharm Sci Res. 2019;10(1):4322-4329. doi: 10.13040/ IJPSR.0975-8232.10(9).4322-29
46. Ganesan AR, Tiwari U, Rajauria G. Seaweed nutraceuticals and their therapeutic role in disease prevention. Food Sci Human Wellness. 2019;8(3):252263. doi: 10.1016/j.fshw.2019.08.001

47. Ramachandran S, Rajasekaran A, Manisenthilkumar K. Investigation of hypoglycemic, hypolipidemic and antioxidant activities of aqueous extract of Terminalia paniculata bark in diabetic rats. Asian Pac J Trop Biomed. 2012;2(4):262-268. doi: 10.1016/s22211691(12)60020-3

48. Selvaraj S, Palanisamy S. Investigations on the anti-diabetic potential of novel marine seaweed $S$. longiotom against alloxan-induced diabetes mellitus: A pilot study. Bangladesh J Pharmacol. 2014;9(2):194197. doi: 10.3329/bjp.v9i2.17304

49. Karthikeyan R, Sundarapandian M. Antidiabetic Activity of Methanolic Extract of Halodule uninervis in Streptozotocin-Induced Diabetic Mice. J Pharm Sci Res. 2017;9(10):1864-1868.

50. Moustafa MM, Rizk MZ, Seoudi DM, Ali SA, Mattloub AAM, Medhat AM. Bioactivity of Enteromorpha intestinalis Polysaccharide Algae Against Hypercholesterolemic Diabetic Rats. Res J Pharm Biol Chem Sci. 2019;10:93-108. 